\title{
Pengaruh Kecerdasan Emosional terhadap Kinerja Karyawan
}

\author{
Aditya Yuda Pratama ${ }^{{ }^{*}}$ dan Tintin Suhaeni ${ }^{2}$ \\ ${ }^{1}$ Jurusan Administrasi Niaga, Politeknik Negeri Bandung, Indonesia \\ ${ }^{2}$ Jurusan Administrasi Niaga, Politeknik Negeri Bandung, Indonesia
}

\begin{abstract}
:
Culinary business from every new is always increas, has always been the highest compared with other types of business. Based on data from the print media, Bandung is designated as an Indonesian culinary destination because it contributes greatly to the state revenue. However, there are problems that often occur especially in the culinary field, one of which is from human resources. This study was conducted to determine the effect of human resources viewed from emotional intelligence to employee performance. The method used is descriptive analysis to obtain the results of emotional intelligence is in the high category and employee performance is also in the high category. The result of simple linear regression analysis obtained equation $Y=13.060+0.420 X$, with $R$ Square of 0.599 means there is contribution between emotional intelligence to employee performance equal to $59.9 \%$.
\end{abstract}

Keywords: culinary, emotional intelligence, employee performance

\begin{abstract}
Abstrak:
Bisnis kuliner dari tahun ke tahun selalu meningkat, meningkatnya bisnis kuliner selalu menjadi yang tertinggi dibandingkan dengan jenis usaha lainnya. Berdasarkan data dari media cetak, Bandung ditetapkan sebagai destinasi kuliner Indonesia karena berkontribusi besar terhadap pendapatan negara. Namun, ada masalah yang sering terjadi terutama di bidang kuliner, salah satunya berasal dari sumber daya manusia. Penelitian ini dilakukan untuk mengetahui pengaruh sumber daya manusia yang dilihat dari kecerdasan emosional terhadap kinerja karyawan. Metode yang digunakan adalah analisis deskriptif dengan hasil kecerdasan emosional berada pada kategori tinggi dan kinerja karyawan juga berada pada kategori tinggi. Hasil analisis regresi linier sederhana diperoleh persamaan $\mathrm{Y}=13,060$ $+0,420 X$, dengan R Square sebesar 0,599 berarti ada kontribusi antara kecerdasan emosional terhadap kinerja karyawan sebesar 59,9\%.
\end{abstract}

Kata Kunci : kuliner, kecerdasan emosional, kinerja karyawan

\section{PENDAHULUAN}

Kota Bandung, Berdasarkan Peraturan Daerah Kota Bandung No 3 Tahun 2014, laju pertumbuhan ekonomi (LPE) Kota Bandung dibandingkan dengan tingkat Jawa Barat dan Nasional di tahun 2008-2012 selalu berada diatas ratarata. Hal ini menunjukkan bahwa Kota

* Email Korespondensi:

Aditya Yuda Pratama

Adityayudapratama.ayp@gmail.com
Bandung menjadi salah satu sumber pertumbuhan ekonomi yang penting. Data tersebut juga menunjukkan bahwa Kota Bandung merupakan Kota yang penting bagi aktivitas ekonomi di Jawa Barat maupun Nasional.

Dalam Kompas.com menyebutkan bahwa Walikota Bandung Ridwan Kamil mempromosikan Usaha Mikro Kecil Menengah (UMKM) dengan cara membuka toko Little Bandung Store di Malaysia, 
dimana program ini adalah kerja sama antara Bandung dan Malaysia melalui Malaysia Indonesia Corporate House.

Berdasarkan sumber dari kementrian koperasi dan UMKM tahun 2012 menyebutkan bahwa UMKM berkontribusi besar terhadap Pendapatan Domestik Bruto (PDB) Indonesia. Jika melihat usaha mikro kecil menengah (UMKM) di Kota Bandung mengalami perkembangan sejak tahun 2000 an. Hal ini disebabkan oleh perkembangan perekonomian di Kota Bandung yang terus menunjukkan peningkatan setiap tahunnya. Sebagai data perkembangan UMKM di kota Bandung dapat dilihat pada tabel satu. Dari tahun ke tahun jumlah penambahan UMKM kuliner selalu mendominasi dibandingkan dengan tipe bisnis lainnya. tahun 20152016 berdasarkan dinas KUMKM dan Perindag Kota Bandung Tahun 2017 penambahan UMKM kuliner lebih dari 57\% atau sebanyak 126 UMKM dari total penambahan keseluruhan sebanyak 220 UMKM.

Tabel 1. Jumlah UMKM Kota Bandung Tahun 2012-2016

\begin{tabular}{|c|c|c|c|c|c|c|}
\hline \multirow{2}{*}{ No } & \multirow{2}{*}{ Ukuran } & \multicolumn{5}{|c|}{ Tahun } \\
\cline { 3 - 7 } & & $\mathbf{2 0 1 2}$ & $\mathbf{2 0 1 3}$ & $\mathbf{2 0 1 4}$ & $\mathbf{2 0 1 5}$ & $\mathbf{2 0 1 6}$ \\
\hline 1 & Mikro & 3.921 & 4.115 & 4.301 & 4.578 & 4689 \\
\hline 2 & Kecil & 337 & 357 & 372 & 392 & 395 \\
\hline 3 & Menengah & 273 & 274 & 275 & 281 & 281 \\
\hline \multicolumn{2}{|c|}{ Jumlah } & 4.531 & 4.746 & 4.948 & 5.251 & 5365 \\
\hline
\end{tabular}

Sumber: Dinas KUMKM dan Perindag Kota Bandung Tahun 2017

Pikiran Rakyat tanggal 23

November 2015, menjelaskan Bandung Ditetapkan sebagai Destinasi Wisata Kuliner Indonesia. Menurut Menteri Pariwisata, sektor kuliner memberikan kontribusi kepada pendapatan Negara sebesar Rp. 208,6 Triliun dengan rata-rata pertumbuhan sekitar 4,5\% pada tahun 2013 lalu. Bahkan unit usaha yang tercipta di sektor kuliner mencapai tiga juta dengan rata-rata pertumbuhan $0,9 \%$.

Disamping pertumbuhan kuliner di Kota Bandung yang baik, terdapat beberapa permasalahan yang dihadapi khususnya sumber daya manusianya. Menurut Kementrian Koordinator Bidang Perekonomian Republik Indonesia tahun 2016 menyebutkan permasalahanpermasalahan yang dihadapi industri kreatif di Indonesia berdasarkan sub sektornya. Disebutkan bahwa sub sektor kuliner memiliki tiga permasalahan, salah satunya adalah Sumber Daya Manusia (SDM).

Didukung dengan wawancara yang telah dilakukan secara informal dengan beberapa karyawan yang berkerja di UMKM kuliner di Kecamatan Sukasari, Bandung, memang sebagian besar karyawan dalam bekerja tidak dalam keadaan sepenuh hati seperti dalam pelayanan yang tidak ramah kepada pelanggan dan beranggapan bahwa mereka hanya berfokus pada memenuhi pesanan yang diminta oleh pelanggan saja. Selain itu dimensi-dimensi dari kecerdasan emosional seperti kesadaran diri (self awareness) dan kesadaran sosial (social awareness) karyawan dapat dikatakan kurang baik hal ini dibuktikan saat mereka melayani pelanggan yang banyak, karyawan tersebut tidak dapat mengontrol kekurangan dirinya seperti kesabaran dan keramahan, sehingga pelanggan yang dilayani merasa kurang puas terhadap pelayanan yang diberikan karyawan. Hal ini mengakibatkan tidak terjadinya loyalitas dari pelanggan sehingga akan mempengaruhi kepada pencapaian kinerja karyawan tersebut. Kemudian hubungan antar karyawan yang kurang adanya kerjasama karena mereka yang bekerja hanya berfokus pada tugasnya masingmasing dan jika tugasnya sudah selesai dikerjakan, mereka tidak melakukan hal lain sampai menunggu tugas berikutnya. Selain hubungan antar karyawan yang kurang baik, hubungan karyawan dengan pelanggan juga kurang terjalin baik, ini disebabkan karena karyawan berkerja 
hanya karena tidak memiliki pilihan tempat bekerja sehingga mereka berfikiran berkerja dimanapun dari pada tidak bekerja sama sekali. Faktor ini yang banyak menjadi alasan mengapa keterampilan sosial mereka di lapangan kurang baik.

\section{KAJIAN LITERATUR \\ Kecerdasan Emosional}

Kecerdasan emosi atau emotional intelligence merujuk pada kemampuan mengenali perasaan kita sendiri dan perasaan orang lain, kemampuan memotivasi diri sendiri, dan kemampuan mengelola emosi dengan baik pada diri sendiri dan dalam hubungan dengan orang lain (Goleman, 2001:512). Kecerdasan emosi sebagai kemampuan merasakan, memahami dan bekerja secara efektif, dan kepekaan emosi sebagai sumber energik informasi, koneksi, dan pengaruh yang manusiawi (Cooper dan Sawaf, 2002 dalam Risma, 2012).

Menurut Goleman (2009:267) terdapat dua faktor yang dapat mempengaruhi kecerdasan emosional, yaitu lingkungan keluarga dan lingkungan non keluarga. Dalam lingkungan keluarga, kehidupan keluarga merupakan sekolah pertama dalam mempelajari emosi. Kecerdasan emosional dapat diajarkan pada saat masih bayi melalui ekspresi. Peristiwa emosional yang terjadi pada masa kanak- kanak akan melekat dan menetap secara permanen hingga dewasa. Kehidupan emosional yang dipupuk dalam keluarga sangat berguna bagi setiap individu dikemudian hari. Lingkungan non keluarga memiliki hal-hal yang terkait yaitu lingkungan masyarakat dan pendidikan. Kecerdasan emosional ini berkembang sejalan dengan perkembangan fisik dan mental. Pembelajaran ini biasanya ditujukan dalam suatu aktivitas seseorang diluar dirinya dengan emosi yang menyertai keadaan orang lain. Disamping dari faktor pengaruh, terdapat pula aspek-aspek dari kecerdasan emosional yang dijelaskan oleh Tridhonanto (2009:11), aspek-aspek kecerdasan emosional suatu individu meliputi kecakapan pribadi, yaitu kemampuan mengelola diri sendiri, kecakapan sosial, yaitu kemampuan menangani suatu hubungan, dan keterampilan sosial, yaitu kemampuan menggugah tanggapan yang dikehendaki orang lain.

Goleman

memberikan lima dimensi untuk mengukur kecerdasan emosional, yang meliputi kesadaran diri, pengaturan diri, motivasi, empati dan keterampilan sosial. Dari tiaptiap dimensi tersebut memiliki beberapa indikator, yaitu pertama, indikator dari dimensi kesadaran diri meliputi kesadaran emosi, penilaian diri dan percaya diri. Kedua, indikator dari dimensi pengaturan diri meliputi kendali diri, sifat dapat dipercaya, dan kewaspadaan. Ketiga, indikator dari dimensi motivasi meliputi dorongan semangat untuk berprestasi, komitmen, inisiatif dan optimis. Keempat, indikator dari dimensi empati meliputi memahami orang lain, orientasi pelayanan, mengembangkan orang lain, dan mengatasi keragaman. Kelima, indikator dari dimensi keterampilan sosial meliputi pengaruh, komunikasi, kepemimpinan, kattalisator perubahan, manajemen konflik, pengikat jaringan, kolaborasi dan kooperasi, dan kemampuan tim. Sedangkan menurut Salovey dan Mayer (2000) dalam Altindag, E \& Kosedagi, Y (2015), terdapat tiga dimensi dari kecerdasan emosional, yaitu evaluasi emosi, pengaturan emosi, dan kemampuan untuk menggunakan emosi sebagai kecerdasan.

\section{Kinerja Karyawan}

Byars dan Rue (2004), mendefinisikan kinerja sebagai derajat 
pencapaian tugas yang diselesaikan karyawan dalam pekerjaannya. Sedangkan menurut Ivancevich et al (2007), "Performance is the level of success in implementing the tasks and the ability to achieve the intended purpose, good performance and successful if the desired goal can be achieved" (Kinerja merupakan tingkat keberhasilan dalam melaksanakan tugas serta kemampuan untuk mencapai tujuan yang telah ditetapkan, kinerja dinyatakan baik dan sukses jika tujuan yang diinginkan dapat tercapai). Lalu menurut Marwansyah (2012:228) yang berpendapat mengenai pengertian kinerja, yaitu pencapaian/prestasi seseorang berkenaan dengan tugas-tugas yang dibebankan kepadanya. Kinerja dapat pula dipandang sebagai perpaduan dari hasil kerja (apa yang harus dicapai oleh seseorang) dan kompetensi (bagaimana seseorang mencapainya). Ada pula pendapat mengenai kinerja menurut Wirawan (2009), kinerja adalah keluaran yang dihasilkan oleh fungsi atau indikator pekerjaan atau suatu profesi dalam waktu tertentu.

Menurut Cornick dan Tiffin (2003:49) menyatakan terdapat dua macam faktor yang dapat mempengaruhi kinerja seseorang, yaitu faktor individual dan faktor situasional. Faktor individual yaitu faktor- faktor yang meliputi sikap, sifat kepribadian, sifat fisik, minat dan motivasi, pengalaman, umur, jenis kelamin, tingkat pendidikan serta faktor individual lainnya. Faktor situasional dikelompokkan menjadi dua. Pertama faktor fisik pekerjaan itu sendiri yang meliputi: metode kerja, kondisi dan desain kerja, perlengkapan kerja, penentuan ruang, dan lingkungan fisik (penyinaran, temperatur dan ventilasi). Kedua, faktor sosial dan organisasi, meliputi: peraturan organisasi, jenis latihan dan pengawasan, sistem upah dan lingkungan sosial. Kemudian terdapat masalah yang disebabkan oleh empat penyebab utama dalam kinerja. Pertama, pengetahuan atau keterampilan. Karyawan tidak tahu bagaimana menjalankan tugas-tugas secara benar kurangnya keterampilan, pengetahuan, atau kemampuan. Kedua, lingkungan. Masalah tidak berhubungan dengan karyawan, tetapi disebabkan oleh lingkungan kondisi kerja, proses yang buruk, ergonomika, dan lain-lain. Ketiga, sumber daya. Kurangnya sumber daya atau teknologi. Keempat, motivasi. Karyawan tahu bagaimana menjalankan pekerjaan, tetapi tidak melakukannya secara benar. Ini mungkin saja disebabkan oleh proses seleksi yang tidak sempurna. (Marwansyah, 2012:234).

Untuk mengetahui apakah kinerja seorang karyawan sudah mencapai target atau belum dapat dilakukan pengukuran kinerjs/prestasi. Pengukuran prestasi kerja adalah kegiatan manajer untuk mengevaluasi perilaku dan prestasi kerja karyawan serta menetapkan kebijaksanaan selanjutnya (Priyono dan Marnis, 2008). Sedangkan menurut Veithzal Rivai (2008) dalam Jaya dkk (2012), menjelaskan pengertian penilaian kinerja adalah hasil kerja yang dapat dicapai oleh seseorang atau kelompok orang dalam suatu perusahaan atau oganisasi sesuai dengan wewenang dan tanggung jawab masingmasing dalam upaya pencapaian tujuan perusahaan secara legal, tidak melanggar hukum dan bertentangan dengan etika. Dalam melakukan penilaian kinerja perlu melalui beberapa langkah. Langkah pertama yaitu mengidentifikasikan tujuan spesifik penilaian kinerja. Contoh tujuan spesifik ini adalah mempromosikan karyawan, mengidentifikasikan kebutuhan pelatihan, mendiagnosis masalah-masalah yang dialami karyawan. Selanjutnya menentukan tugas-tugas yang harus dijalankan dalam sebuah pekerjaan (analisis jabatan). Deskripsi jabatan yang akurat, yang dihasilkan dari 
analisis jabatan, menjadi masukan terpenting bagi penentuan faktor-faktor penilaian yang benar-benar terkait dengan jabatan. Jika analisis jabatan sudah dilakukan, pada tahap ini cukup dilakukan upaya untuk memutakhirkan atau melengkapi informasi hasil analisis jabatan. Kemudian memeriksa tugastugas yang dijalankan. Pada tahap ini, penilai memeriksa tugas-tugas yang dilaksanakan oleh tiap-tiap pekerja, dengan berpedoman pada deskripsi jabatan. Pada dasarnya, pemantauan dan pencatatan atas pelaksanaan tugas-tugas dapat dilakukan setiap saat. Meskipun demikian, banyak organisasi atau perusahaan yang menetapkan waktu pemantauan berkala, misalnya setiap empat bulan. Lalu menilai kinerja. Setelah memeriksa tugas-tugas, penilai memberikan nilai untuk tiap-tiap unsur jabatan yang diperiksa atau diamati. Terakhir membicarakan hasil penilaian dengan karyawan. Pada tahap terakhir ini, penilai hendaknya menyampaikan dan mendiskusikan hasil penilaian kepada karyawan yang dinilai. Karyawan yang dinilai dapat mengklarifikasikan hasil penilaian dan, bila perlu, bisa mengajukan atas hasil penilaian. Langkah-langkah diatas perlu direncanakan dan diimplementasikan secara cermat dan konsisten agar dapat menjamin tercapainya tujuan-tujuan penilaian kinerja (Marwansyah, 2010). Ivancevich et al (2007) dalam melakukan penilaian terhadap kinerja karyawan berdasarkan deskripsi perilaku yang spesifik, terdapat beberapa dimensi atau kriteria yang perlu diperhatikan diantaranya, yaitu: pertama, kuantitas kerja (Quantity of work) adalah jumlah kerja yang dilakukan dalam suatu periode waktu yang ditentukan. Kedua, kualitas kerja (Quality of work) adalah kualitas kerja yang harus dicapai berdasarkan syarat-syarat yang ditentukan perusahaan dan kesiapan dalam menyelesaikan pekerjaan. Ketiga, pengetahuan Kerja (Knowledge of job) adalah luasnya pengetahuan mengenai pekerjaan dan keterampilan. Keempat, kualitas personal (Personal qualities) adalah menyangkut kepribadian, kepemimpinan, keramah tamahan dan integritas pribadi. Kelima, kerjasama (Cooperation) adalah kesediaan untuk bekerja dengan orang lain sesame anggota organisasi. Keenam, dapat dipercaya (Dependability) adalah kesadaran dan dapat dipercaya dalam hal kehadiran dan menyelesaikan pekerjaan. Terakhir yaitu ketujuh, inisiatif (Initiative) adalah semangat untuk melaksanakan tugas-tugas baru dan dalam memperbesar tanggungjawabannya.

\section{METODE PENELITIAN \\ Populasi dan Sampel}

Populasi UMKM Kuliner di Kecamatan Sukasari Bandung yaitu sebanyak 946 UMKM yang dihitung secara manual dengan mengamati langsung ke lapangan. Penulis hanya mengambil sebagian kecil populasi mengingat banyaknya populasi yang tidak memenuhi kriteria UMKM Kuliner di Kecamatan Sukasari Bandung yang ditentukan dalam penelitian ini. Sampel yang diambil yaitu 39 UMKM dengan jumlah kuesioner yang disebar sebanyak 142 yang diberikan kepada karyawan UMKM Kuliner di Kecamatan Sukasari Bandung. Teknik sampling yang digunakan dalam penelitian ini adalah non probility sampling dengan cara pengambilan sampel menggunakan purposive sampling. Adapun kriteria UMKM Kuliner di Kecamatan Sukasari Bandung yang dijadikan responden yaitu minimal usaha yang sudah berjalan satu tahun dan dalam satu organisasi minimal memiliki tiga karyawan. Dalam pengumpulan data, peneliti menggunakan teknik wawancara dan teknik kuesioner (angket) dalam pengumpulan datanya. 
HASIL DAN PEMBAHASAN

Hasil Identitas Responden

Dari hasil penyebaran kuesioner (angket) kepada 39 organisasi dengan jumlah responden 142 didapat data berdasarkan jenis kelamin, usia, tingkat pendidikan, dan masa kerja. Dari data tersebut didapat responden dengan jenis kelamin laki-laki yang mendominasi yaitu sebanyak 113 orang. Sedangkan dari usia responden didapat data responden paling banyak yang berumur 17-25 tahun sebanyak 119 orang. Adapulan data responden dilihat berdasarkan tingkat pendidikan didapat responden yang berpendidikan SMA/SMK mendominasi sebanyak 136 orang. Terakhir yaitu dari masa kerja karyawan didapat sebanyak 64 orang sudah bekerja 1-2 tahun, sedangkan dengan masa kerja 2-3 tahun sebanyak 49 orang, lalu sebanyak 24 orang bekerja sudah 3-5 orang, dan sisanya sudah bekerja lebih dari lima tahun.

\section{Analisis Deskriprif Variabel Kecerdasan Emosional}

Analisis ini digunakan untuk menjawab identifikasi masalah penelitian tentang tingkat kecerdasan emosional yang dimiliki karyawan UMKM Kuliner di Kecamatan Sukasari Bandung. Pada tabel dua merupakan hasil statistik deskriptif dari variabel kecerdasan emosional sesuai dengan yang dirasakan dan dialami oleh responden.

Tabel 2. Statistik Deskriptif Kecerdasan Emosional

\begin{tabular}{|l|l|l|l|l|l|}
\hline & N & Min & Max & Mean & $\begin{array}{l}\text { Std. } \\
\text { Dev }\end{array}$ \\
\hline Kesadaran Diri & 39 & 2 & 5 & 3.84 & .450 \\
\hline Pengaturan Diri & 39 & 2 & 5 & 3.93 & .438 \\
\hline Motivasi & 39 & 2 & 5 & 3.76 & .527 \\
\hline Empati & 39 & 2 & 5 & 3.91 & .372 \\
\hline Keterampilan & 39 & 2 & 5 & 4.03 & .494 \\
\hline Kecerdasan & 39 & 2 & 4.62 & 3.8969 & .364 \\
\hline
\end{tabular}

Sumber : Hasil olah data SPSS (2017)

Melihat semua dimensi kecerdasan

emosional yang digunakan, didapat bahwa kecerdasan emosional karyawan UMKM Kuliner di Kecamatan Sukasari Bandung berada dalam kategori "Tinggi", sesuai dengan tabel dua dengan rata-rata sebesar 3.8969, nilai tersebut berada pada interval $3.41-4.20$, yang artinya variabel kecerdasan emosional karyawan UMKM Kuliner di Kecamatan Sukasari Bandung sudah digunakan dengan intensitas tinggi saat bekerja. Sedangkan untuk tingkat variansi dari tiap-tiap dimensi pada variabel kecerdasan emosional berada dibawah $20 \%$ yang artinya rendah. Dimensi tertinggi pada variabel ini yaitu keterampilan sosial dengan nilai mean (rata-rata) sebesar 4.03 karena ini berhubungan langsung dengan orang lain, pada dimensi ini kecerdasan emosional diaplikasikan secara langsung dengan orang lain. Sedangkan dimensi terendah pada variabel ini yaitu motivasi dengan nilai mean (rata-rata) sebesar 3.76 .

Dimensi pertama dari variabel kecerdasan emosional adalah kesadaran diri yang memiliki nilai mean (rata-rata) sebesar 3,84, nilai tersebut berada pada interval $3.41-4.20$, yang berarti kesadaran diri karyawan UMKM Kuliner di Kecamatan Sukasari Bandung berada pada kategori "Tinggi". Menurut Goleman (2001:83) Kesadaran diri merupakan keterampilan dasar yang sangat vital untuk tiga kecakapan emosi. Pertama, kesadaran emosi, mereka mengetahui tentang bagaimana pengaruh emosi terhadap kinerjanya, dan kemampuan untuk menggunakan kelebihan dari mereka untuk membuat suatu keputusan. Kedua, penilaian diri secara akurat, mengetahui kelebihan dan kekurangan yang ada pada diri mereka dan mencoba untuk memperbaiki kekurangannya. Ketiga, percaya diri, keberanian yang muncul dari kemampuan, kelebihan, dan tujuan mereka. Hal ini menunjukkan bahwa karyawan UMKM Kuliner di Kecamatan 
Sukasari Bandung memiliki keterampilan dasar untuk kesadaran emosi, penilaian diri yang secara akurat dan percaya diri dimana ketiga kecakapan emosi itu merupakan keterampilan dasar yang vital.

Dimensi ke dua dalam variabel kecerdasan emosional adalah pengaturan diri dengan nilai mean (rata-rata) sebesar 3,93 yang berada pada interval 3,40 - 4,20 yangmana nilai tersebut berada pada kategori "Tinggi". Hal menunjukkan bahwa kemampuan karyawan dalam mengatur dirinya sudah sangat baik, dengan melalui kemampuan mengatur diri yang baik maka sebagian dari kecerdasan emosional yang dimiliki karyawan UMKM Kuliner di Kecamatan Sukasari Bandung akan tergolong baik Goleman (2001) menyebutkan bahwa terdapat beberapa kemampuan yang berkaitan erat dengan kecerdasan emosi salah satunya yaitu kendali diri (pengaturan diri). Lalu kerangka kemampuan emosional mewakili bagaimana untuk mengatur diri sendiri dengan melalui mengelola diri sendiri dan memotivasi diri.

Dimensi ke tiga dalam variabel kecerdasan emosi yaitu motivasi dengan nilai mean (rata-rata) sebesar 3,76 yang berada pada interval 3,41 - 4,20 dengan demikian menunjukkan berada pada kategori "Tinggi". Hal ini menunjukkan bahwa karyawan UMKM Kuliner di Kecamatan Sukasari Bandung mampu memotivasi dirinya dengan berinisiatif, percaya diri, memiliki tujuan serta dorongan mereka untuk berprestasi dengan memanfaatkan kesempatan untuk meminpin di saat bekerja. Pernyataan ini sesuai dengan pendapat menurut Priyono dan Marnis (2008:15) yang mengatakan bahwa prestasi kerja karyawan dimotivasi oleh keinginan untuk mencapai tujuan. Selain itu agar seseorang memiliki motivasi yang tinggi perlulah kecakapan- kecakapan seperti dorongan berprestasi, komitmen dan inisiatif serta optimisme (Goleman, 2001:181).

Dimensi Empati merupakan dimensi yang ke empat dengan nilai mean (rata-rata) sebesar 3,91 yang berada pada interval 3,41 - 4,20 yang berarti berada dalam ketegori "Tinggi". Hal ini menunjukkan babwa karyawan UMKM Kuliner di Kecamatan Sukasari Bandung mampu memahami apa yang diinginkan orang lain dan mampu untuk memenuhi yang dibutuhkan oleh pelanggan, hal ini dapatlah terjadi karena menurut Goleman (2001:214-215) empati merupakan radar sosial seseorang, sehingga dengan adanya radar yang tinggi, maka kemampuan karyawan dalam memahami terhadap apa yang diinginkan oleh orang lain terutama pelanggan dapat terpenuhi.

Dimensi terakhir pada variabel kecerdasan emosional yaitu keterampilan sosial dengan nilai mean (rata-rata) sebesar 4,03 yang berada pada interval 3,40 - 4,20 sehingga dimensi ini masuk ke dalam kategori yang tinggi. Dimensi ini merupakan dimensi tertinggi diantara dimensi-dimensi kecerdasan emosional lainnya yang digunakan pada penelitian ini. Hal ini membuktikan bahwa keterampilan sosial yang merupakan pengaplikasian dari variabel kecerdasan emosional karyawan sudah dapat dilakukan dengan baik seperti hal yang dilakukannya seperti mengtahui emosi anggota tim melalui perilakunya, keefektifak dalam berkomunikasi dengan orang lain terutama dengan pelanggan. Pernyataan tersebut didukung dengan pendapat menurut Prawitasari (1998) hal terpenting dalam kecerdasan emosi yaitu dapat belajar untuk mengenali emosi orang lain dan belajar untuk mengubah polanya. Selain itu juga pendapat menurut Goleman (2001) menyebutkan bahwa terdapat tujuh kemampuan yang berkaitan erat dengan kecerdasan emosi diantaranya yaitu rasa 
ingin tau mengenaik orang lain dan kecakapan berkomunikasi.

\section{Deskriptif Variabel Kinerja Karyawan}

Untuk mengidentifikasi masalah mengenai tingkat kinerja karyawan pada UMKM Kuliner di Kecamatan Sukasari Bandung.

Dimensi yang keempat yaitu kualitas personal. Nilai mean (rata-rata) dimensi ini yaitu sebesar 4,15 yang berada pada interval3.40 - 4.20 sehingga berada pada kategori yang "Tinggi". Angka ini menjelaskan bahwa kualitas personal dari karyawan UMKM kuliner di Kecamatan Sukasari Bandung memiliki tingkat yang tinggi. Kualitas personal yang dimiliki karyawan UMKM kuliner di Kecamatan Sukasari Bandung seperti mampu berkomunikasi dengan tim atau rekan kerja, mampu berkomunikasi dengan pelanggan, dan bekerja sesuai jam kerja yang telah ditentukan. Pernyataan tersebut didukung oleh pendapat dari Hasibuan (2007) yang menjelaskan bahwa kinerja individu akan tercapai apabila didukung oleh atribut dari individu itu sendiri (kemampuan, keahlian, latar belakang demograf, attitude, kualitas personal, motivasi), upaya kerja dan dukungan organisasi. Kemampuan karyawan UMKM Kuliner di Kecamatan Sukasari Bandung dalam berkomunikasi salah satu contoh yang dapat diambil dari hasil pengamatan dilapangan, mereka mampu menjalin hubungan dengan baik dengan rekan kerja maupun pelanggan sehingga akan mendatangkan keuntungan bagi dirinya maupun perusahaan, yaitu pencapaian jumlah kerja karena loyalitas pelanggan dan kualitas personal yang tinggi sehingga karyawan tersebut akan mendapatkan bonus dari atasan karena pencapaian dari jumlah kerja tersebut.

Dimensi yang kelima pada variabel

kinerja karyawan yaitu kerjasama. Nilai mean (rata-rata) dimensi kerjasama yaitu sebesar 4,04 yang berada pada interval $3.40-4.20$ sehingga tergolong pada kategori "Tinggi". Hal ini mengindikasikan bahwa karyawan UMKM kuliner di Kecamatan Sukasari Bandung mampu bekerjasama dengan baik saat bekerja, seperti bekerjasama dengan tim atau rekan kerja dan juga bekerjasama dengan atasan. Akan tetapi berbeda dengan kondisi yang ada di lapangan, terdapat UMKM yang karyawannya kurang melakukan kerjasama. Hal ini disebabkan karena ketidaksungguhan mereka dalam berkerja, beberapa karyawan beranggapan mereka bekerja hanya sekedar datang dan menyelesaikan tugas mereka tanpa mempedulikan pekerjaan yang dilakukan orang lain. Sehingga mereka bekerja dalam keadaan tidak bersungguhsunggung. Mangkunegara (2008) menyebutkan bahwa kerjasama merupakan salah satu aspek penting dalam kinerja, jika seorang karyawan tidak mampu bekerjasama dengan rekan tim maupun atasan makan kinerja mereka dikategorikan kurang dalam hal kerjasama. Dimensi berikutnya yaitu dimensi yang keenam, yaitu dimensi dapat dipercaya. Nilai mean (rata-rata) dari dimensi dapat dipercaya yaitu sebesar 3,92 yang berada pada interval $3.40-4.20$ sehingga masuk pada kategori "Tinggi". Angka ini menjelaskan bahwa karyawan UMKM kuliner di Kecamatan Sukasari Bandung dapat dipercaya saat melakukan pekerjaan yang ditugaskan kepadanya, seperti dapat diandalkan atasan untuk menyelesaikan tugas sesuai dengan bidang kerja, dan mampu bekerja dengan baik dan serius meskipun atasan tidak ada ditempat kerja. Hal ini didukung dengan pendapat dari Robbins dan Timothy (2013) bahwa individu yang kuat akan memiliki perbedaan yang signifikan terhadap tingkat dapat dipercayanya. Seperti kebanyakan karyawan UMKM Kuliner di Kecamatan Sukasari Bandung dalam melakukan pekerjaannya tidak 
memandang apakah atasan berada ditempat kerja maupun tidak, mereka berfokus untuk melayani pelanggan dan berusaha untuk memenuhi kebutuhan pelanggan, akan tetapi beberapa karyawan UMKM Kuliner di Kecamatan Sukasari Bandung juga jika saat tidak diawasi, mereka tidak bekerja dengan baik, seperti dalam hal pelayanan kepada pelanggan berupa komunikasi yang kurang baik sehingga pelanggan merasa tidak puas dan enggan untuk membeli produk yang dijual tersebut.

Tabel 3. Statistik Deskriptif Kinerja Karyawan

\begin{tabular}{|c|c|c|c|c|c|}
\hline & $\mathrm{N}$ & Min & Max & Mean & $\begin{array}{l}\text { Std. } \\
\text { Dev }\end{array}$ \\
\hline Jumlah Kerja & 39 & 1 & 5 & 3.72 & .724 \\
\hline Kualitas Kerja & 39 & 3 & 5 & 4.05 & .560 \\
\hline $\begin{array}{l}\text { Pengetahuan } \\
\text { Mengenai }\end{array}$ & 39 & 3 & 5 & 4.23 & .536 \\
\hline Kualitas & 39 & 4 & 5 & 4.15 & .403 \\
\hline Kerjasama & 39 & 3 & 5 & 4.04 & .518 \\
\hline Dapat & 39 & 3 & 5 & 3.92 & .480 \\
\hline Inisiatif & 39 & 2 & 5 & 3.74 & .677 \\
\hline Kinerja & 39 & 3.07 & 4.67 & 3.97 & .353 \\
\hline
\end{tabular}
variabel kinerja karyawan yaitu inisiatif. Nilai mean (rata-rata) dimensi inisiatif yaitu sebesar 3,74 yang berada pada interval 3.40 - 4.20 sehingga berada pada golongan "Tinggi". Angka ini menunjukkan bahwa inisiatif karyawan UMKM kuliner di Kecamatan Sukasari Bandung tinggi, seperti keberanian mereka dalam menyampaikan saran atau kritik yang berkaitan dengan pekerjaan kepada atasan atau rekan kerja, dan berinisiatif untuk menyelesaikan tugasnya. Pernyataan tersebut dikuatkan dengan pendapat Mankunegara (2009), inisiatif merupakan semangat seseorang dalam menyelesaikan tugas serta mampu membuat keputusan yang baik tanpa adanya pengarahan terlebih dahulu dari orang lain. Sesuai dengan kenyataan yang terjadi di lapangan, sebagian besar karyawan UMKM Kuliner di Kecamatan
Sukasari Bandung memiliki inisiatif yang tinggi, hal ini dibuktikan dengan kemampuan mereka membuat keputusan untuk menyiapkan persediaan terlebih dahulu sehingga saat pelanggan datang dan memesan sudah siap dan dapat terlayani dengan cepat, selain itu keberanian mereka untuk menyampaikan kritik atau saran kepada atasan meskipun keputusan ada di tangan atasan.

\section{Analisis Korelasi}

Berdasarkan tabel 4, dapat dilihat bahwa nilai korelasi antara variabel kecerdasan emosional dengan kinerja karyawan adalah sebesar 0.774. Angka ini terdapat pada interval 0,60-0,799 yang berarti kecerdasan emosional dengan kinerja karyawan memiliki hubungan positif yang kuat. Nilai korelasi pearson pada tabel diatas menunjukkan nilai positif, maka hubungan antara kecerdasan emosional dengan kinerja karyawan adalah searah, yang berarti jika kecerdasan emosional meningkat maka akan diikuti oleh peningkatan kinerja karyawan.

Tabel 4. Analisis Korelasi

\begin{tabular}{|l|l|l|l|}
\hline \multicolumn{2}{|c|}{} & $\begin{array}{l}\text { Kecer } \\
\text { dasan } \\
\text { Emosio } \\
\text { nal }\end{array}$ & $\begin{array}{l}\text { Kinerja } \\
\text { Karya } \\
\text { wan }\end{array}$ \\
\hline \multirow{3}{*}{$\begin{array}{l}\text { Kecerdasan } \\
\text { Emosional }\end{array}$} & $\begin{array}{l}\text { Pearson } \\
\text { Correlation }\end{array}$ & 1 & $.774^{* *}$ \\
\cline { 2 - 4 } & Sig. (2-tailed) & & .000 \\
\cline { 2 - 4 } & N & 39 & 39 \\
\hline \multirow{3}{*}{$\begin{array}{l}\text { Kinerja } \\
\text { Karyawan }\end{array}$} & $\begin{array}{l}\text { Pearson } \\
\text { Correlation }\end{array}$ & $.774^{* *}$ & 1 \\
\cline { 2 - 4 } & Sig. (2-tailed) & .000 & \\
\cline { 2 - 4 } & N & 39 & 39 \\
\hline
\end{tabular}

Sumber : Hasil olah data SPSS (2017)

\section{Analisis Regresi Linear}

Analisis regresi linear digunakan untuk memprediksi bagaimana perubahan nilai kecerdasan emosional jika nilai kinerja karyawan pada UMKM Kuliner di Kecamatan Sukasari Bandung dinaikkan atau diturunkan. Untuk memperoleh 
persamaan regresi dari penelitian mengenai pengaruh kecerdasan emosional terhadap kinerja karyawan, dapat dilihat pada tabel lima.

Tabel 5. Analisis Regresi

\begin{tabular}{|l|l|l|l|l|l|}
\hline \multirow{2}{*}{ Model } & \multicolumn{2}{|c|}{$\begin{array}{l}\text { Unstandardied } \\
\text { Coefficients }\end{array}$} & $\begin{array}{l}\text { Standardizd } \\
\text { Coefficients }\end{array}$ & T & Sig. \\
\cline { 2 - 5 } & B & $\begin{array}{l}\text { Std. } \\
\text { Error }\end{array}$ & Beta & & \\
\hline Constant) & 13.060 & 4.194 & & 3.114 & .004 \\
\hline $\begin{array}{l}\text { Kecerdasan } \\
\text { Emosional }\end{array}$ & .420 & .057 & .774 & 7.434 & .000 \\
\hline
\end{tabular}

Sumber : Hasil olah data SPSS (2017)

Berdasarkan tabel 5 dapat dilihat bahwa nilai konstanta (a) sebesar 13.060 sedangkan nilai koefisien regresi (b) sebesar 0.420. Oleh karena itu, persamaan regresi yang dapat diperoleh dalam penelitian ini adalah $\mathrm{Y}=13.060+0.420 \mathrm{X}$. Nilai a dan $b$ dapat diartikan sebagai berikut :

1) Konstanta sebesar 13.060 dapat diartikan jika kecerdasan emosional bernilai $(\mathrm{X}=0)$ maka kinerja karyawan yang tercapai hanya sebesar 13.060.

2) Kecerdasan emosional memiliki nilai koefisien regresi linear sebesar 0,420. Ini berarti setiap penambahan satu angka kecerdasan emosional dengan koefisien bernilai positif, maka kinerja karyawan akan mengalami peningkatan sebear 0,420 .

\section{Koefisien Determinasi}

Koefisien determinasi digunakan untuk mengetahui kemampuan variabel independen dalam menerangkan variabel dependen. Dimana jika nilai R mendekati angka satu, maka variabel independen tersebut memberikan hampir semua informasi yang dibutuhkan untuk memprediksi variabel dependen. Hasilnya dapat dilihat pada tabel enam berikut :
Tabel 6. Koefisien Determinasi

\begin{tabular}{|l|l|l|l|l|}
\hline Model & $\mathrm{R}$ & $\begin{array}{c}\mathrm{R} \\
\text { Square }\end{array}$ & $\begin{array}{c}\text { Adjusted } \\
\text { R Square }\end{array}$ & $\begin{array}{c}\text { Std. Error } \\
\text { of the } \\
\text { Estimate }\end{array}$ \\
\hline 1 & .774 & .599 & .588 & 2.418 \\
\hline
\end{tabular}

Sumber : Hasil olah data SPSS (2017)

Hasil koefisien determinasi antara kecerdasan emosional terhadap kinerja karyawan menunjukan nilai 0,599. Dengan demikian kecerdasan emosional dapat memberikan berkontribusi terhadap kinerja karyawan sebesar 59,9\%. Sementara sisanya $40.1 \%$ dipengaruhi faktor-faktor lain yang tidak di teliti dalam penelitian ini.

\section{Pengaruh Kecerdasan Emosional terhadap Kinerja Karyawan}

Berdasarkan hasil dari data yang telah diolah, diperoleh hasil yang menunjukkan bahwa terdapat hubungan antara kecerdasan emosional terhadap kinerja karyawan. Hal ini dibuktikan dengan hasil dari analisis korelasi antara variabel kecerdasan emosional terhadap variabel kinerja karyawan sebesar 0,774 yang termasuk dalam hubungan positif yang kuat. Menurut Sugiyono (2013) jika nilai $\mathrm{R}$ berada pada interval 0,60-0,799 maka termasuk dalam kategori kuat.

Kecerdasan emosional juga memiliki pengaruh positif terhadap kinerja karyawan dalam analisis regresi yang dilakukan. Hal tersebut dapat dilihat dari persamaan analisis regresi linear sederhana yang dihasilkan, yaitu $\mathrm{Y}=13.060+$ 0,420X. Diketahui nilai konstanta (a) sebesar 13.060 dan koefisien regresi (b) menunjukkan angka 0,420 yang berarti saat ada penambahan satu angka kecerdasan emosional dengan koefisien regresi bernilai positif maka kinerja karyawan akan meningkat. Melihat dari tabel koefisien determinasi, kecerdasan emosional memberikan kontribusi sebesar 59.9\% terhadap kinerja karyawan, sisanya 
sebanyak $40.1 \%$ lainnya dipengaruhi oleh faktor lain yag tidak di teliti dalam penelitian ini. Menurut Mangkunegara (2009:4) mengemukakan bahwa dalam hubungannya dengan pencapaian kinerja karyawan yang tinggi, perlu dilandaskan pada beberapa pendekatan, salah satunya adalah pendekatan psikologis dari karyawan itu sendiri dan organisasi. Pendekatan psikologis dan organisasi terhadap kinerja ini diantaranya adalah pendekatan terhadap kepribadian dan kecerdasan emosional dari sumber daya manusia yang ada di dalam perusahaan. Sedangkan menurut Goleman (2001:84) mengetahui bagaimana kesadaran diri akan mempengaruhi kinerja sebab menentukan sasaran yang akan dicapai diperlukan pengetahuan terhadap diri sendiri Dari tabel uji statistik $F$, nilai $F$ hitung yang didapat adalah 55.268 dimana nilai $\mathrm{F}$ tabelnya adalah 4.10, yang berarti $\mathrm{F}$ hitung lebih besar dari $\mathrm{F}$ tabel. Nilai sigifikansi dari dari perhitungan adalah sebesar 0,000, dimana angka tersebut kurang dari 0,05 . Hal ini dapat disimpulkan bahwa Ho ditolak dan $\mathrm{H}_{\mathrm{a}}$ diterima. Ini menunjukkan adanya pengaruh yang signifikan antara kecerdasan emosional terhadap kinerja karyawan. Kemudian berdasarkan uji t, diperoleh nilai t hitung sebesar 7.434 dan nilai t tabelnya sebesar 2.024. Berdasarkan data tersebut, dapat disimpulkan nilai t hitung lebih besar dibandingkan dengan $\mathrm{t}$ tabel. Ini berarti $\mathrm{H}_{\mathrm{a}}$ diterima dan Ho ditolak. Hal ini juga menunjukkan adanya pengaruh positif dan signifikan antara kecerdasan emosional dengan kinerja karyawan UMKM Kuliner di Kecamatan Sukasari Bandung. Nilai probabilitas yang ditampilkan pada tabel juga menunjukkan angka yang lebih kecil dari 0.05 , yaitu 0,000. Dengan demikan, model regresi dapat digunakan untuk memprediksi kinerja karyawan UMKM Kuliner di Kecamatan Sukasari Bandung.

\section{KESIMPULAN DAN SARAN}

\section{Kesimpulan}

1. Kecerdasan emosional yang dimiliki karyawan UMKM Kuliner di Kecamatan Sukasari Bandung berada pada kategori tinggi, dilihat dari lima dimensi dari variabel kecerdasan emosional, yaitu kesadaran diri, pengaturan diri, motivasi, empati, dan keterampilan sosial yang berada pada ketegori tinggi. Jika diurutkan dari dimensi dengan mean tertinggi sampai dengan mean terendah yaitu keterampilan sosial, pengaturan diri, empati, kesadaran diri, dan motivasi.

2. Kinerja karyawan UMKM Kuliner di Kecamatan Sukasari Bandung yaitu tinggi. Hal ini menunjukkan bahwa kayawan UMKM Kuliner di Kecamatan Sukasari Bandung dalam melakukan pekerjaannya mampu memenuhi dimensi-dimensi kinerja dengan kategori yang tinggi. Dapat dilihat pada tujuh dimensi dari variabel kinerja karyawan, yaitu jumlah kerja, kualitas kerja, kualitas personal, kerjasama, dapat dipercaya, dan inisiatif yang berada pada kategori tinggi, sedangkan dimensi pengetahuan mengenai pekerjaan berada pada kategori yang sangat tinggi. Jika diurutkan dari dimensi dengan mean tertinggi sampai dengan mean terendah yaitu pengetahuan mengenai pekerjaan, kualitas personal, kualitas kerja, kerjasama, dapat dipercaya, inisiatif, dan jumlah kerja.

3. Terdapat pengaruh positif dan signifikan antara kecerdasan emosional terhadap kinerja karyawan. Kecerdasan emosional memberikan kontribusi sebesar $59,9 \%$ terhadap kinerja karyawan. Sementara sisanya dipengaruhi faktor-faktor lain yang tidak diteliti.

\section{Saran}


Berdasarkan kesimpulan yang telah dipaparkan, ada beberapa saran yang dapat diberikan, yaitu sebagai berikut:

1. Pihak manajemen memperhatikan pemberian gaji karyawan yang sesuai dengan upah minimum Kabupaten/Kota (UMK) agar karyawan merasa terjamin dari hal gaji sehingga mereka merasa nyaman saat bekerja dan kecerdasan emosional karyawan akan terus tinggi.

2. Untuk menjaga dan meningkatkan kinerja, karyawan diwajibkan mampu mencapai jumlah yang ditargetkan, menciptakan produk dengan kualitas yang sesuai dengan standar dari perusahaan, memiliki pengetahuan mengenai pekerjaan yang dilakukannya melalui pelatihan di bidangnya.

3. Diharapkan agar penelitian ini dapat dilanjutkan oleh peneliti selanjutnya dengan membandingkan objek penelitian yang lebih luas lagi serta dengan karakteristik yang berbeda.

\section{DAFTAR PUSTAKA}

Altindag, E., \& Kosedagi, Y. (2015). The Relationship between Emotional Intelegence of Managers Innovative Corporate and Employee Performance. Procedia - Social and Behavioral Sciences.

Byars, L. L., \& Rue, L. W. (2004). Human Resourching Management (7th ed). New York: Mc Graw Hill.

Cornick, M., \& Tiffin. (2003). Manajemen Kinerja. Bandung: Alfabeta.

Goleman, D. (2001). Working with Emotional Intelligence: Kecerdasan Emosi untuk Mencapai Puncak Prestasi. Jakarta: Gramedia Pustaka Utama.

Goleman, D. (2009). Emotional Intelligence: Kecerdasan Emosional, Mengapa EI Lebih Penting dari IQ.

Jakarta: Gramedia Pustaka Utama.
Hasibuan, H. M. (2007). Manajemen Sumber Daya Manusia. Jakarta: Bumi Aksara.

Ivancevich, J. M., Konopaske, R., \& Matteson, M. T. (2007). Perilaku dan Manajemen Organisasi Edisi (Diterjemahkan oleh: D. Yuwono). Jakarta: Erlangga.

Jaya, M. P., Mulyadi, D., \& Sulaeman, E. (2012). Pengaruh Kecerdasan Emosional terhadap Kinerja Karyawan pada Kantor Kementrian Agama Kabupaten Karawang. Jurnal Manajemen Vol. 10 No. 1

Mangkunegara, A. P. (2008). Manajemen Sumber Daya Manusia Perusahaan. Bandung: Remaja Rosdakarya.

Mangkuprawira. (2009). Bisnis Manajemen dan Sumber Daya Manusia. Bogor: IPB Press.

Marwansyah. (2010). Sumber Daya Manusia. Bandung: Alfabeta. 